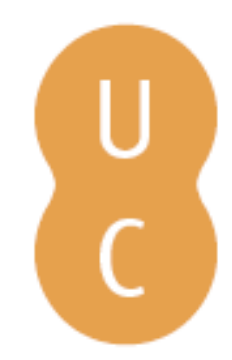

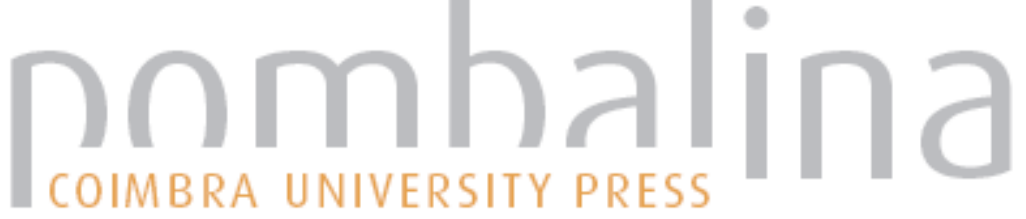

\section{O motivo do sonho no romance de Cáriton}
Autor(es):
Silva, Maria de Fátima
Publicado por: Centro de Estudos Clássicos e Humanísticos
URL persistente:
URI:http://hdl.handle.net/10316.2/39246
DOI:
DOI:http://dx.doi.org/10.14195/978-989-26-1229-4_4

Accessed : $\quad$ 26-Apr-2023 12:18:04

A navegação consulta e descarregamento dos títulos inseridos nas Bibliotecas Digitais UC Digitalis, UC Pombalina e UC Impactum, pressupõem a aceitação plena e sem reservas dos Termos e Condições de Uso destas Bibliotecas Digitais, disponíveis em https://digitalis.uc.pt/pt-pt/termos.

Conforme exposto nos referidos Termos e Condições de Uso, o descarregamento de títulos de acesso restrito requer uma licença válida de autorização devendo o utilizador aceder ao(s) documento(s) a partir de um endereço de IP da instituição detentora da supramencionada licença.

Ao utilizador é apenas permitido o descarregamento para uso pessoal, pelo que o emprego do(s) título(s) descarregado(s) para outro fim, designadamente comercial, carece de autorização do respetivo autor ou editor da obra.

Na medida em que todas as obras da UC Digitalis se encontram protegidas pelo Código do Direito de Autor e Direitos Conexos e demais legislação aplicável, toda a cópia, parcial ou total, deste documento, nos casos em que é legalmente admitida, deverá conter ou fazer-se acompanhar por este aviso.

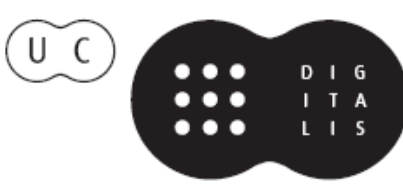


FRANCISCO DE OLIVEIRA

PAOLO FEDELI

DELFIM LEÃO

Coordenadores

\section{- ROMANCE ANTIGO ORIGENS DE UM GÉNERO LITERÁRIO}

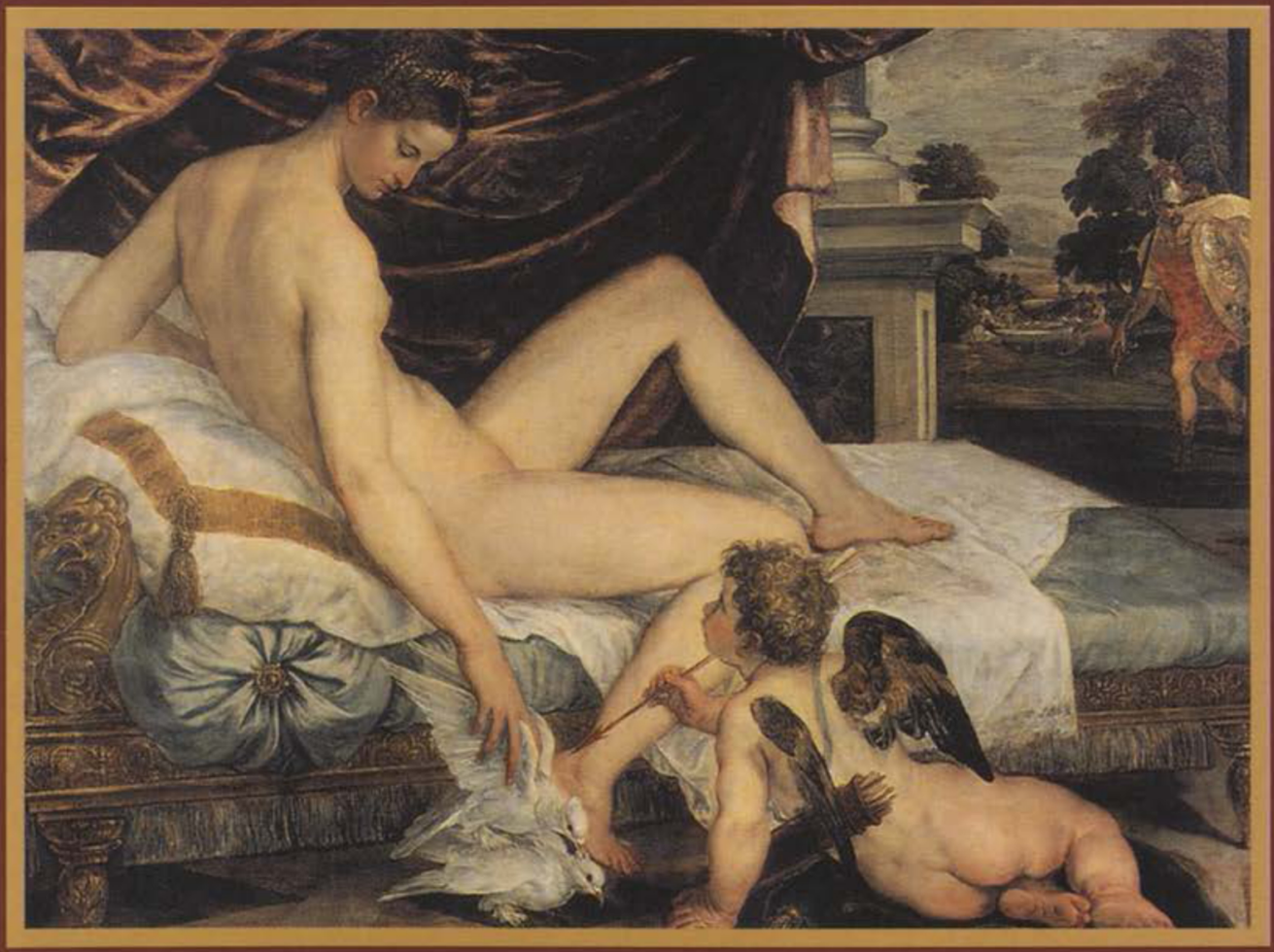

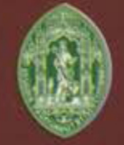

Universidade de Coimbra

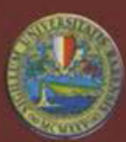

Università degli Studi di Bari

COIMBRA

2005 


\title{
O MOTIVO DO SONHO NO ROMANCE DE CÁRITON
}

\author{
MARIA DE FÁTIMA SILVA \\ Universidade de Coimbra
}

\begin{abstract}
Résumé: Le rêve, avec toutes ses conventions littéraires et dramatiques, est fréquent chez les auteurs de l'ancien roman grec, qui l'ont adapté aux exigences du genre. Chariton, qui y revient souvent, fait du rêve la projection de la réalité, utilisable comme un point de départ des grandes étapes de son discours narratif. Simple de traits, le rêve joue dans son oeuvre un rôle significatif pour le dessein des charactères et pour la compréhension du fil de l'intrigue.
\end{abstract}

O género romance representa uma última invenção na vitalidade diacrónica da literatura grega antiga; depois das glórias do passado - as poesias épica e lírica, o teatro e a historiografia -, o romance apareceu, já em plena época helenística, como uma florescência tardia, que desde logo suscitou muitas reservas e críticas. Insuspeitada foi, porém, à partida, a perenidade que o novo modelo literário viria a ter entre os vindouros, num percurso que ainda não viu o seu limite.

Mas nunca foi contestada a relação que o romance teve com toda a tradição literária anterior. Desde a épica, a primeira narrativa extensa a contemplar a viagem aventureira, passando pela historiografia, até ao teatro, com a sua tendência para a análise dos comportamentos humanos sob uma forma dramática e directa, de todos os seus antepassados o romance se tornou um repositório natural. E como narrativa de aventuras e de amor que é, são suas fontes principais os poemas épicos, Eurípides e a comédia nova. Para além dos motivos temáticos, o romance esteve também atento a processos de estilo e de estratégia narrativa que a mesma tradição the oferecia, largamente testados e aperfeiçoados por séculos de utilização. Sem que, no entanto, os autores do romance deixassem de ter ainda a capacidade de encontrar, para padrões gastos pelo tempo, um último fôlego de adaptação ou criatividade.

O motivo que nos propomos tratar especificamente - o sonho conheceu uma fidelidade permanente nos diversos géneros, com destaque maior para a épica e a tragédia. Inicialmente concebido como um 
meio privilegiado de comunicação entre os deuses e os homens, sobretudo os que detêm na mão a autoridade e interferem no destino do mundo, o sonho foi-se tornando, com o tempo, um fenómeno relacionado com a psicologia humana e revelador de sentimentos ou de preocupações íntimos. Mas quer o sonho espelhe a vontade superior dos deuses, como projecte as apreensões do dia-a-dia, sempre funcionou como estimulador de uma reacção que leva o homem a agir, ou pondo em concreto as supremas determinações da divindade, ou tentando, com subterfúgios sempre votados ao fracasso, evitar o poder inabalável do destino e das forças que comandam o universo.

Em conformidade com a natureza mais sobrenatural ou mais humana do fenómeno, assim o sonho se revela mais como a imagem exterior e distante de um mensageiro divino inacessível ao contacto humano, ou se identifica com a própria consciência; esta exprime-se então em imagens ou palavras, permitindo até a comunicação entre o indivíduo e a projecção de si próprio, no que pode tornar-se uma 'conversa com o travesseiro'; deste modo se clarificam decisões e se sujeita a alma humana a um processo de introspecção ou de auto-análise. Depois deste momento de solidão, que corresponde ao confronto do homem com o sonho, é comum que se suceda o da comunicação, com um intérprete que decida do sentido do sonho, com um confidente ou mesmo com um cúmplice, que oiça, opine e se alie na acção que vulgarmente se sucede.

Uma leitura do romance de Cáriton nesta perspectiva surpreende desde logo pelo número de ocorrências de sonhos que contém. Não se trata, portanto, de uma utilização pontual, mas de um fenómeno insistente, que marca pontos de partida decisivos para as grandes etapas do fluir da ficção'. A coajuvar a simplicidade geral na técnica narrativa de Cáriton, que o colocou na posição do autor do romance mais antigo que conservamos ${ }^{2}$, também os sonhos por ele criados são de uma linearidade exemplar, claros na mensagem, evidentes na interpretação, mas eficazes como projecções da realidade.

Registemos, antes de mais, o sonho associado à personalidade do chefe, de que o exemplo da experiência de Agamémnon na abertura do Canto II da Ilíada é decerto um paradigma incontornável. Está iminente o início de uma arremetida decisiva numa campanha que se pro-

${ }^{1}$ Para uma síntese bibliográfica sobre o assunto e para a sua valorização no romance de Cáriton, cf. D. Auger (1983), 'Rêve, image et récit dans le roman de Chariton', Ktema 8, 39-52.

${ }^{2}$ Talvez o romance de Cáriton date do séc. I d. C. 
longa sem resultados definitivos. Mas o sonho épico contempla claramente dois níveis, o divino antes de mais, e o humano. Mais do que a preocupação de Agamémnon pela intervenção ou sorte dos homens que comanda, é a de Zeus, pelo cumprimento do compromisso assumido com Tétis, de honrar Aquiles no diferendo que o separa do Atrida, que se impõe. Verdadeiramente senhor da acção, Zeus não dorme, mas enquanto todo o universo cede, tranquilo, a morfeu, o pai dos deuses procura, na insónia, a decisão que cabe à sua autoridade suprema (Ilíada 2. 1 sqq.). Logo, através do seu emissário, o sonho que o olímpico envia à tenda de Agamémnon com as suas ordens, o poeta alerta para o sentido relevante da insónia, como uma circunstância que afecta seres superiores a quem incumbem grandes responsabilidades. É à laia de repreensão que o sonho interpela o Atrida, como os demais adormecido (2. 24-25): "Um herói não deve dormir a noite inteira, se pertence ao número daqueles que tomam parte no Conselho, que tem a seu cargo os povos e a quem tantos cuidados estão reservados". Com esta observação, o autor da Ilíada desperta a atenção dos seus ouvintes para o facto de ser Zeus, na sua insónia responsável, e não Agamémnon, o chefe dos exércitos e a autoridade suprema sobre a campanha que se desenrola às portas de Tróia. A insónia é o emblema daquele a quem o exercício do comando compete.

Cáriton transfere a réplica desta situação para a figura de um outro chefe, Téron, o pirata ${ }^{3}$. O plano é, neste caso, estritamente humano, a personagem um marginal aventureiro. Mas esta figura, que o autor de Afrodísias desenha com minúcia, corresponde a um chefe, concentrado no objectivo que norteia uma vida de risco - o lucro-, que depende também da intervenção competente dos homens sob sua orientação. Mesmo se invertido no estatuto e nos ideais - sendo o indivíduo sem escrúpulos, que actua em nome do dinheiro um novo modelo de herói -, o episódio que lança Téron na grande campanha da sua carreira de salteador tem indubitavelmente alguma inspiração épica. Em primeiro lugar, a insónia acompanha a decisão de avançar contra um território de risco, mas capaz de satisfazer toda a sua ambição, o túmulo que, debaixo dos seus olhos, se tornara a arca de um tesouro (1. 7. 1): "O tal fulano por acaso presenciou o funeral, ficou na mira do ouro e, de noite, na cama, não havia forma de pregar olho". Naquele que é o cenário habitual do sonho literário, cercado de trevas, silêncio e solidão, decorre o momento de alerta ou de reflexão, que se

${ }^{3}$ Fica desde logo claro por esta opção que o sonho no romance de Cáriton não é exclusivo dos heróis centrais da história. 
exprime pela insónia. Em vez de um diálogo com o além, é o solilóquio que se instala. O que, na insónia de Zeus, se resume a uma interrogativa com que o poeta formula, em tom geral, as apreensões do pai dos deuses - em seu coração, o deus medita: como, para honrar Aquiles, poderá ele destruir, junto das suas naus, os Aqueus aos milhares?, Iliada 2. 3-4 -, desdobra-se, no caso de Téron, numa multiplicidade de interrogações pessoais. Ao fluir monótono da narrativa, Cáriton substitui a corrente de consciência da personagem, o pirata que, nas respostas que encontra para as próprias perplexidades, pinta o seu autoretrato (1. 7. 1-2). Mais do que promover o assalto a um túmulo, o autor do romance deixa entrever em Téron as motivações pessoais que promovem tal acto; ao contabilizar o risco maior a que se sujeita quem assalta vivos por lucros de miséria, em comparação com quem investe contra a inércia da morte por lucros chorudos, o pirata revela o calculismo frio que, associado à ganância, dá ao crime naturalidade e justificação. $\mathrm{O}$ espírito que assim raciocina não se deixa perturbar por inibidores princípios de humanidade ou pela pressão da lei; a lógica que o guia é estritamente financeira e traduz-se na proporção simples de menos riscos igual a mais lucros. Este é, levado ao extremo, um outro herói do universo dos negócios, onde o individualismo domina, quando se esbateu, no horizonte do homem que passou a movimentarse em todo o espaço mediterrânico, o efeito coercivo das regras da polis ${ }^{+}$.

Se é rápida e determinada a adesão de Téron a uma empresa de sentido extremo, logo, dentro do mesmo pragmatismo, se sucede no seu espírito a decisão de uma estratégia adequada, que cabe a um chefe competente definir. Motivar os homens sob seu comando e seleccionálos de acordo com as suas aptidões é uma garantia de sucesso. Ao rever os seus colaboradores, recapitulando em cada um deles a principal virtude ao lado do defeito mais visível - um que é 'astucioso' mas 'cobarde', outro que embora 'determinado' é 'falso', 1. 7. 2 -, Téron aprofunda o seu retrato de salteador, passando do nível superficial dos comportamentos para outro, interior, do ethos. Neste processo Téron passou a noite, fazendo consigo próprio o que Agamémnon realizou com o apoio do Conselho dos aristoi que o rodeavam: a preparar a

${ }^{4}$ G. L. SChMeling (1974), Chariton (New York) 90, chama a atenção para o facto de os piratas, que são comuns no romance grego, não terem abundado na realidade dos séc. I-II d. C. Admite por isso que Cáriton estivesse a usar uma convenção que prosseguiu até ao seu tempo, ou a introduzir no romance uma tonalidade histórica que correspondia ao séc. V a. C. Assaltantes de túmulos, esses continuavam a ser comuns. 
estratégia que pudesse estimular à acção, sem reservas ou discordâncias, os guerreiros que queria conduzir à conquista de uma fortaleza promissora e ambicionada. Com um solilóquio ditado pela insónia, Cáriton dava à técnica do retrato um dinâmica viva, eficaz, completa, que trazia ao discurso narrativo diversidade e força.

Se foi este o processo literário que o autor de Quéreas e Calirroe encontrou para pôr em acção o pirata Téron e assim promover o rapto e o distanciamento da sua heroína, insónia e sonho voltam a afectar o sequestrador no momento de consumar os seus objectivos, com a venda da jóia suprema do seu tesouro, a bela Calírroe. De Mileto esperava Téron a solução para o seu negócio, como uma terra onde o dinheiro abundava e o afã das transacções parecia garantir a convulsão financeira necessária a uma venda ilícita e clandestina. Entre a avaliação da capacidade do mercado e o temor pela abordagem de um comprador poderoso, capaz de responder a um negócio de fôlego, mas talvez senhor de uma curiosidade excessiva, Téron passou longos dias acumulando angústias, tecidas pela insegurança e pela demora. Por isso o sono o abandonou de novo, deixando à insónia e ao solilóquio a vez para prolongarem, na solidão da noite, as preocupações do momento (1. 12. 2). A repetição do processo anterior, para assinalar uma outra hora decisiva na empresa que o pirata executava, não significa simplesmente a insistência inútil numa convenção antes ensaiada. A verdade é que a repetição da experiência pela mesma personagem permite detectar o efeito que o tempo e os acontecimentos desencadearam sobre o aventureiro, enriquecendo o retrato geral do pirata. O risco inesperado, o facto de a morta, senhora do túmulo e do tesouro, ter afinal ressuscitado, desencadeou em Téron cuidados e inseguranças. Porque a mercadoria a negociar era de carne e osso e tinha voz, o perigo tornou-se ameaçador e a confiança do assaltante saiu abalada da surpresa. No limite da preocupação, uma nova insónia vai surpreendê-lo; ao Téron racional substitui-se um outro, 'insensato e estúpido' avóetos, como o próprio reconhece - em dificuldades para tomar uma decisão fria e pragmática. A ansiedade quebrou-lhe os nervos de aço. Uma linha de continuidade faz, mesmo assim, do comportamento deste herói uma peça única e coerente, a sua preocupação com o lucro e o dinheiro. Mas sobre os tesouros que tem consigo acumulam-se agora não promessas sedutoras, mas riscos tenebrosos: vindos de fora, de concorrentes no mundo sem lei dos salteadores, ou mesmo dos seus homens, a quem escrúpulos e lealdade não incomodam. A mesma lucidez com que a insónia anterior media os méritos de cada um dos seus subordinados, em nome de interesses comuns, no solilóquio actual 
traduz-se em desconfiança, fazendo avultar os defeitos sobre as qualidades e deixando adivinhar em cada um deles um traidor. Por isso o solilóquio não conduz à acção determinada, como na hora do assalto ao túmulo, mas à reserva e à imobilidade. E esta traduz-se em sono e em adiamento, de uma decisão que é preciso tomar e que o desespero dita extrema: atirar ao mar o incómodo tesouro humano e, de uma vez, liquidar riscos e preocupações. É este o impasse, de sinal negativo, que precede o sono, negativo para Téron, porque equivale à ruína de um projecto lucrativo, mas negativo também para Calírroe e para o decurso de uma aventura que está longe ainda de atingir o seu fim. É a alteração destes propósitos que o sono e o sonho vão ter a função de desencadear, um e outro essenciais à reversão da acção futura. Sobre a experiência da noite Cáriton é muito parco em pormenores, porque se limita a uma breve observação (1. 12. 5): "Então adormeceu e viu em sonhos as portas fechadas. Decidiu por isso ficar mais aquele dia". Se a presença do divino no sonho não é patente, dele resulta no entanto um sinal explícito, que sugere a suspensão dos propósitos de abandono e partida, que no momento anterior determinavam o pirata. O sonhador captou do sonho esse pormenor fundamental, que se exprimia de uma forma simbólica, interpretou-o por si próprio e decidiu agir em conformidade. Neste gesto de bom senso, que talvez acima de tudo a superstição comandasse, Téron deu um sinal de regresso à prudência e ao pragmatismo que the eram próprios, encontrando numas horas de sono o melhor conselheiro para os seus propósitos e para o curso da história. Depois desta decisão acertada, o destino se encarregou de conduzir, sem demora, os acontecimentos por uma via auspiciosa. Já o comprador ideal se perfilava diante do aventureiro, ao mesmo tempo que o tema do amor se recolocava ao leme da acção. Em conformidade, a intervenção do sonho, como mola de decisão e do avanço do intriga, mudava de campo.

Dentro de um esquema que a comédia muito utilizou, com processos progressivamente mais eficazes, a intervenção de um servo antecipa a aparição e interferência do senhor. Antes que Cáriton nos apresente Dionísio de Mileto, o novo pretendente de Calírroe, antecipa a sua vida e preocupações através de Leone, o seu homem de confiança ${ }^{5}$. É com o intendente que Téron estabelece um primeiro con-

${ }^{5}$ São conhecidas cenas famosas da comédia de Aristófanes que usam esta estratégia. O Eurípides de Acarnenses, como o Ágaton de Tesmofórias, ou o Tereu de Aves, personagens a quem o poeta quer dar o destaque de seres exóticos ou fantásticos, têm um criado que é a sua imagem fiel e que antecipa, em cena, os traços do seu patrão 
tacto, fazendo do seu produto uma publicidade apropriada a um verdadeiro negociante. Se o potencial comprador, o ainda distante Dionísio, é rico, nobre, viúvo e pai de uma órfã, que melhor oferta lhe poderia ser proposta do que uma mulher jovem e bonita, capaz de desempenhar o papel de ama da criança ou, quem sabe, de consolar também a tristeza depressiva de um viúvo desolado (1. 12. 6-9)? O acerto dos argumentos usados pelo traficante torna-se evidente na reacção de Leone. Tal como o patrão adiante será protagonista de um sonho revelador das suas preocupações mais íntimas, também antes o procurador avança com o seu próprio sonho, motivado pelo momento que a casa que serve experimenta (1.12.10): 'Foi um deus que te enviou como meu salvador. Vens realizar o sonho que eu tive'. Curiosamente não é necessário, desta vez, descrever a visão que assaltara o sonho nocturno de Leone. A projecção do sonho é dada ao vivo pela chegada e pela proposta de Téron. É óbvio, do laconismo da observação proferida pelo intendente de Dionísio, que o sonho de Leone foi ditado pela lealdade, que fazia dos tormentos do seu senhor preocupações assumidas como próprias. O sonho é portanto, neste caso, a garantia de profunda fidelidade de um servo, como também a mola que trará a essa philia uma colaboração activa. Mas, para além do seu sentido humano e psicológico, este sonho denuncia a intervenção divina no destino dos homens, pela própria coincidência que o associa à aparição de um estranho e à proposta que vem fazer. É a vontade humana, patrocinada pela determinação divina, que irá levar Calírroe a cumprir, no seu destino, uma segunda etapa: o casamento com Dionísio.

Depois de, à distância, termos vislumbrado num simples relance o senhor de Mileto - "um homem maduro, vestido de negro e com um ar triste", 1. 12. 5 -, o primeiro contacto directo que nos é facultado com ele colhe-o na ressaca de um sonho. É a Leone, o confidente do momento, que ele descreve a visão que teve, no centro da qual se encontrava a sua mulher, entretanto falecida. Todo o quadro envolvente deste sonho profético apontava para a excepção e anunciava o fim do sofrimento causado pelo luto. Depois de uma longa insónia,

\footnotetext{
e prepara, com vantagem, a aparição espectacular da estranha personagem. Por outro lado, ao servo porteiro, que é a imagem viva do interior da casa, soma-se, no plano da intriga amorosa que a comédia nova privilegiou, o seruus callidus, autor de intrigas e tramóias para levar a bom termo os anseios apaixonados do seu senhor. Está aberto o caminho ao futuro escravo plautino, cérebro de uma estratégia que desanuvia dificuldades e viabiliza os sonhos de um par romântico; por isso o vemos sair de cena premiado com todas as coroas da vitória. Leone possui alguns matizes destes dois tipos dramáticos, embora sem o fulgor de que a comédia os dotou.
} 
esta tinha sido a primeira noite de um sono tranquilo para o viúvo. A imagem da falecida liquidara angústias e rodeava-se de um sinal auspicioso. Com este momento, Cáriton retomava cenas célebres do teatro euripidiano, em que o sonho repunha o carinho entre esposos que a morte separou, como Alceste e Admeto, ou Laodamia e Protesilau ${ }^{6}$. Tal como Admeto, Dionísio poderia dizer (Alceste 355-356): "É doce, nem que seja de noite, ver quem amamos, por pouco tempo que seja". A somar à tranquilidade que cercou o seu sonho, outros sinais o garantiram como de bom augúrio. Do conteúdo festivo se pressente um indício de felicidade: o sonho, que não se exprime por palavras, é uma imagem que convida Dionísio a rever o dia feliz do seu primeiro casamento; do centro do cortejo nupcial, que desfila ao som de himeneu, projecta-se a figura da desposada, 'mais alta e mais irresistível' ainda do que era na realidade $(2.1 .2)^{7}$. Desde logo Leone brada a feliz coincidência entre o sonho que acabava de ouvir relatar e as notícias de que era portador; pode, por isso, avançar uma interpretação segura, fácil, evidente (2.1.3): "É a felicidade que te bate à porta, senhor, no sonho e na vida real. Prepara-te para ouvir o facto que bate certo com essa visão". Ainda que discretamente, a mão divina é perceptível, concorrendo com o seu alto patrocínio para o bom sucesso das acções que, em paralelo, a vontade humana vai desencadeando ${ }^{8}$.

Se a presença dos deuses é, apesar de tudo, discreta no sonho que trouxera a Dionísio um sopro de paz após a tormenta da sua vida, ela é patente na visão paralela que será determinante para lançar Calírroe nos braços de um novo esposo. A preparar um primeiro encontro, a jovem vê em sonhos a própria Afrodite, numa imagem silenciosa mas claramente identificada. Sem qualquer hesitação, Calírroe toma a iniciativa que se impunha, dirigir-se ao templo para adorar a deusa (2. 3. 5). É então sob o patrocínio divino que o encontro entre os dois

${ }^{6}$ Cf. Alceste 348-356, em que Admeto imagina o sonho, para além da morte de Alceste, induzido por uma estátua, moldada por mão de artista, que virá substituir no leito conjugal a mulher perdida, como triste consolação para a ausência irreparável da morte. A mesma ideia figurava no Protesilau, como conforto para Laodamia, abandonada após uma só noite de núpcias, por um Protesilau, que viria a ser, no desembarque dos Aqueus em Tróia, a primeira vítima dos dardos inimigos. Há, no texto do romance de Cáriton, uma alusão a Protesilau, 5. 10. 1.

${ }^{7}$ Esta noção de que a figura que aparece em sonhos se impõe por uma estatura e beleza fora do comum é uma convenção do motivo: cf. Ésquilo, Persas 184-185; Heródoto 7. 12.

${ }^{8}$ Parece-me excessiva a opinião de Auger, op. cit., 43, que exclui por completo a interferência divina nos sonhos de Cáriton. 
se processa. Mas para cada um o sonho e as suas consequências vêm marcados com um sinal contrário; porque se, para Dionísio, eles representam a terapia que o poderia arrancar a uma nostalgia suicida, para Calírroe, a vítima de um destino controverso, era ambígua a hora que vivia; se auspiciosa, por the trazer a segurança e a protecção de que o exílio dos seus a deixava privada, era mesmo assim condenatória da fidelidade eterna que desejava manter intacta para o seu primeiro amor, o saudoso Quéreas.

É decerto em nome dessa mesma fidelidade, uma componente incontornável do romance grego de amor e aventuras, que Cáriton se demora na avaliação dos pressupostos que envolvem as bodas previsíveis da sua heroína com o senhor de Mileto; este casamento, que é a quebra de um elo afectivo, antes de mais de um viúvo inconsolável perante a memória da mulher, mas principalmente da heroína do romance com o amante perdido e herói da mesma história, tem de ser justificado, como infracção que parece ser à própria convenção literária.

Num movimento crescente, é primeiro de Dionísio que o autor se ocupa, que recolhe ao leito, depois de uma festa nocturna entre amigos, para reviver, na solidão e na insónia, as sensações do encontro com Calírroe. Dentro da mesma configuração literária antes usada para Téron na investida contra o túmulo, que lhe traria a posse da filha de Hermócrates, também Dionísio avalia, entre a insónia e o solilóquio, o contorno de uma outra apropriação do mesmo tesouro, a beleza de Calírroe. Depois de um encontro ao vivo, no templo de Afrodite, que fora por inteiro um hino aos sentidos, olhos e ouvidos do senhor de Mileto mobilizados pela imagem de perfeição que se lhes oferecia, a recordação desse episódio a sós é, como o próprio o reconhece, 'um combate entre a razão e a paixão' (2. 4. 4). A cena do encontro é, assim, não apenas repetida, mas aprofundada e justificada nas suas consequências. À experiência perturbadora, mas momentânea, vivida em presença de Calírroe (2. 3. 6-7), substitui-se agora o pormenor, a soma de detalhes que constroem a imagem de conjunto. Recuperado o cenário - o templo de Afrodite - a memória devolve, ao apaixonado insone, uma nova visão, rosto, cabelos, gesto, olhos, voz, porte, as palavras que a bela proferiu (2. 4. 3). Por este processo, Cáriton encontra ensejo para repetir a descrição da perfeição física da sua heroína, uma convenção insistente no género. Mas mais importante do que esta confirmação é a revelação de uma alma, atormentada pelo escrúpulo, que o solilóquio seguinte manifesta. Dionísio patenteia-se digno do perfil que é legítimo esperar do senhor de Mileto; o debate 
que trava é o de um homem maduro, responsável, com deveres públicos e uma dignidade a defender, em combate com arroubos amorosos de adolescente; é-o também de um viúvo, na iminência de quebrar o elo que o prendia ainda à memória da sua defunta mulher. E em nome de quê põe Dionísio em risco o seu ascendente de grande senhor? Do encanto de uma simples escrava, cuja identidade e posse continuam ainda obscuras. Com esta tomada de consciência, Dionísio salvaguarda o estatuto, mesmo diante de uma estranha e até censurável paixão. De resto, a decisão tremenda que o momento exige, entre a resistência ou a cedência à paixão, não é sua, mas depende da intervenção do amigo Leone, o procurador fiel, homem de negócios cuja personalidade mais facilmente the permite erguer a bandeira do pragmatismo, que satisfaz anseios e traz salvação aos tormentos de uma alma. Mais uma vez a insónia e o solilóquio são postos ao serviço da caracterização da personagem, de forma a que não perca de todo a identidade dentro do fluir imposto pela convenção da intriga.

À medida que o interesse e a aproximação do novo pretendente se vai consolidando, Cáriton prepara, do lado de Calírroe, uma justificação equivalente, com recurso a igual processo, a insónia e o solilóquio (2. 9. 2-6). À pobre exilada está reservado um tremendo debate entre a mulher e a mãe, quando uma gravidez resultante do seu primeiro casamento inesperadamente se revela. A Calírroe exposta em Mileto às arremetidas de um novo apaixonado é a mesma mulher que traz no ventre o fruto de um amor que jurou eterno, pelo seu Quéreas. No cativeiro, abandonada pelo homem que ama e pai do seu filho, Calírroe tem de decidir a sorte da criança: provocar um aborto e condenar à morte esse filho sem pai e exposto a circunstâncias adversas? Ou correr o risco e permitir a vinda ao mundo de um filho que, quem sabe, se portador da nobreza e da coragem dos seus, não poderá vir a tornar-se o salvador da mãe e o autor do reencontro de uma família desgarrada pela sorte? O que, na reflexão paralela de Dionísio, se exprimiu dentro de critérios subordinados ao estatuto pessoal, social e político, colocase agora dentro de parâmetros convenientes ao estatuto da mulher, como o são a honra, a fidelidade conjugal e a maternidade. À insónia seguiu-se o sonho, breve, mas expressivo, trazendo a resposta que faltava a um espírito perturbado. Neste caso, em que a heroína sonha com um philos saudoso e perdido, Cáriton confessa o modelo em que se inspira, com uma citação da Ilíada (23. 66-67), que corresponde ao sonho de Aquiles depois da perda de Pátroclo. Tal como o Pelida, Calírroe viu a imagem de Quéreas em tudo semelhante à real; "era a sua estatura, a beleza dos olhos, a voz e, a envolver-lhe o corpo, as 
mesmas vestes" (2. 9. 6). Tal como a aparição de Pátroclo, também a de Quéreas falou, agora em palavras muito breves, mas decisivas: "Confio-te, mulher, o nosso fillho". Calírroe, à semelhança de Aquiles, tentou o contacto físico, estendeu os braços na tentativa de um enlace; sem sucesso, porque a visão esvaiu-se antes de desaparecer (cf. Iliada 23. 99-101; Cáriton 2. 9. 6). Entre o sonho épico e a sua réplica romanesca, o paralelo é evidente: domina a afectividade, entre o sonhador e a visão, que determina o apelo à philia de quem se encontra ausente. A decisão que a visão desencadeia produz uma reacção imediata. Logo a Siracusana cede e se predispõe a aceitar um segundo casamento; se acolhe a paixão de Dionísio não é por si, mas por esse filho abandonado e pelo pai ausente que o gerou. Sem dúvida que, na sua devotação a Quéreas, Calírroe entende que esta nova união, de necessidade, não interfere com a dedicação devida ao primeiro marido. Como heroína de romance, a personagem ganha talvez, por este acto, uma flexibilidade e realismo maiores, o que justifica a infracção ao esquema permanente de fidelidade na novela ${ }^{9}$.

Depois de fazer progredir a aventura de Calírroe, Cáriton promove o movimento do herói, Quéreas, que parte em busca da esposa perdida. A um conjunto de situações que têm por pólo a figura passiva e emocionalmente patética de Calírroe, corresponde, para Quéreas, a necessidade, a cada passo renovada, de lutar contra os sucessivos agentes das contingências que o afastam da mulher amada. Embora, à superfície, os dois heróis da história se mantenham afastados e lançados num jogo de exílio de um e de perseguição do outro, a separação física de que são vítimas, como bem regista REARDON ${ }^{10}$, é mais aparente do que real, porque eles se mantêm perto, de forma que o romancista possa estabelecer entre eles contactos, de grande efeito na textura da intriga. Essa proximidade de que se suspeita - evidente no mesmo templo de Afrodite que ambos visitam e onde um retrato é a prova material da sua passagem, ou no episódio do incêndio da trirreme de Quéreas, cuja notícia, intencionalmente deturpada, chega a Calírroe -, além de um estímulo à fidelidade mútua, é sobretudo um factor de permanente ironia, por levar cada um dos protagonistas a dúvidas ou a conclusões opostas à realidade. Um elemento transcendente torna-se recurso vulgar neste processo à distância: o sonho, que prossegue no

${ }^{9}$ Sobre as interpretações suscitadas por este episódio e a sua relação com a fidelidade da heroína do romance, cf. S. WIERSMA (1990), 'The ancient Greek novel and its heroines: a female paradox, 'Mnemosyne 43, 117 sqq.; D. KONSTAN (1994), Sexual symmetry (Princeton) 50-51.

${ }^{10}$ (1982), 'Theme, structure and narrative in Chariton, 'YClS 27, 21. 
romance o seu efeito de mensageiro profético, pelas interpretações díspares que por vezes proporciona, ao serviço da ironia.

A acompanhar a saga verdadeira do seu amado, Calírroe vê, em sonhos, Quéreas prisioneiro (3. 7. 4); embora seja uma visão da realidade, o processo não permite entre ambos a comunicação desejada; dentro do sonho as palavras não são consentidas a Quéreas, que apenas acena, como quem remete uma mensagem. Tão enigmático como as próprias palavras, este silêncio repercute-se no exterior, quando a jovem grita, pela primeira vez na presença do novo companheiro de leito, Dionísio, o nome do seu antigo apaixonado. Com este brado involuntário, Calírroe vê-se obrigada a partilhar com o senhor de Mileto uma página da sua vida que até agora deixara oculta. E o resultado que a situação produz é contraditório: porque se para Calírroe o sonho significa um sinal da morte efectiva do seu amado, para Dionísio ele constitui um alerta da ameaça de um rival, até então desconhecido. Mas logo um segundo sonho inverte as posições, como uma espécie de quiasmo dramático; Calírroe, de novo com Quéreas diante dos olhos adormecidos, sonha que o salva (4. 1. 1), enquanto Dionísio pretende ver nesse sinal a exigência de um morto para que the sejam prestadas honras fúnebres e promove o segundo funeral do romance. O modelo homérico da solicitação de Pátroclo, junto de um Aquiles adormecido, de rituais de morte, reaparece numa menção explícita da Ilíada 23. 71, com que o senhor de Mileto pretende pôr uma pedra sobre a angústia da mulher, como sobre a sua própria insegurança, sepultando de uma só vez um amante e um rival. Como outrora em Siracusa, agora em Mileto, um enterro parece colocar uma lápide sobre um amor apaixonadamente vivido; apenas, agora como então, o túmulo que se encerra está vazio e vivo o seu habitante imaginário. É como se, da estreiteza do túmulo, se irradiasse um horizonte sem fronteiras, porque Quéreas, que se quer encerrar num féretro faustoso, está na Cária, que é domínio do sátrapa Mitradates, de novo afastado da mulher de luto que o chora. Mas também - ironia suprema! - o gesto de Dionísio, que visava liquidar um concorrente, produz o efeito inverso, porque não só não encerra um episódio da vida de Calírroe - o amor por Quéreas -, como abre outro, igualmente ameaçador: a pretensão apaixonada de Mitradates, presente no funeral, à beleza fascinante de Calírroe. Discretos nos contornos e nos pormenores, os dois sonhos da senhora de Mileto são decisivos no curso dos acontecimentos, pelas reacções que provocam. E como é apanágio dos sonhos, é exactamente a tentativa de lhes aniquilar os efeitos que os torna efectivamente actuantes. 
O curso da história irá mostrar que o acto calculado de Dionísio, de sepultar Quéreas, continuará a desencadear consequências a longa distância. Assim, convencido da concorrência de Mitradates junto da sua mulher, o tirano de Mileto diligencia por uma resolução, em tribunal, deste atentado contra a sua segurança familiar. Tudo aponta no sentido de um clímax, que terá lugar em Babilónia sob a presidência do poderoso rei da Pérsia, onde se irá consagrar a beleza de Calírroe e estabelecer finalmente, sem mais ambiguidades, o seu legítimo possuidor. Oculta ainda neste agôn final estava apenas a investida do último dos pretendentes da heroína, o maior de todos os senhores do mundo, o monarca Artaxerxes ${ }^{11}$. O sonho regressa em torno deste episódio supremo, aquele que vai permitir que Quéreas e Calírroe se vejam de novo, mesmo se o abraço final sofre ainda um adiamento novelesco.

É justamente na noite que precedeu esse encontro inesperado, na sala do tribunal, que Calírroe experimenta o seu último sonho. Apanhada pela angústia que acompanhava os passos extremos da sua vida, sujeita a esperar de uma sentença judicial o curso do destino, a jovem teve a visão de uma felicidade que julgava perdida (5. 5. 5): "Viu-se em Siracusa, ainda menina, a dirigir-se ao templo de Afrodite; ao sair, vislumbrava Quéreas. Era o dia do casamento; a cidade inteira cobriase de coroas, o pai e a mãe levavam-na, no cortejo nupcial, a caminho da casa do noivo. Ia dar um beijo a Quéreas, quando acordou do sonho". Tal como antes Dionísio revia o dia das suas primeiras bodas no momento em que a felicidade de novo the sorria, também Calírroe recebia, no auge de uma vida de adversidades, um sinal de bom augúrio. Incapazes de aderirem sem reservas a tão grande mudança no seu destino, um e outro se valeram de um confidente, outrora um servo fiel, Leone o procurador, um homem próximo de Dionísio, e agora Plângon, a criada de Calírroe. Mas mais do que uma promessa de desafogo de uma alma atormentada, este último dos sonhos da heroína enlaçava também todas as pontas da história, passadas e futuras. Com

1 Também Artaxerxes é, no romance, objecto de dois sonhos que são, mesmo assim, laterais ao desenvolvimento da história. O primeiro (6. 2. 2) é uma visão régia, dentro de um plano de comunicação natural entre o senhor da Pérsia e os deuses, de acordo com a melhor tradição oriental. No entanto, ao adiar o julgamento a que presidia e onde se disputava o futuro de Calírroe com base numa exigência divina de sacrificios, o soberano servia também os seus interesses de apaixonado da heroína, que assim mantinha por mais algum tempo na corte e acessivel à sua abordagem amorosa. Um segundo sonho de Artaxerxes (6. 7. 1-2), precedido de insónia, vem confirmar o desassossego crescente deste último coração também rendido à beleza dominadora de Calirroe. Do ascendente de um soberano inspirado pelos deuses, Artaxerxes reduz-se ao papel de um vulgar apaixonado. 
ele se revive o início do romance, o primeiro encontro com Quéreas (1. 1. 5-6) e as bodas dos dois jovens (1. 1. 14-16); ao mesmo tempo que se anuncia o encontro final do par $(8.1 .8)$ e as suas novas núpcias (8. 1. 12-17). É o curso total de uma aventura que se condensa nas breves linhas que relatam este sonho, na sua forma anelar.

Como sempre, ao longo do romance, cada personagem, de acordo com os anseios da sua mente e do seu coração, fará dos sinais transmitidos pelo sonho a sua leitura, resultando de cada informação o fluir de percepções contraditórias. Mas é frequente que a visão nocturna não passe de uma mera antecipação da realidade. Esta simplicidade no registo do sonho, que não exige do intérprete uma grande perspicácia, coincide com a opinião que Plângon, neste momento interpelada por Calírroe, exprime sobre o sentido das visões nocturnas (5. 5. 5): "Foi belo o sonho que tiveste. Vais ver-te liberta de uma angústia terrível. Porque o que viste em sonhos, vai passar-se também na realidade". É esta a leitura que faz do processo ancestral do sonho um novo género literário, construído sobre errâncias, perigos e sofrimentos, mas comprometido com a exigência inabalável de um final feliz.

\section{BIBLIOGRAFIA}

D. AUGER, "Rêve, image et récit dans le roman de Chariton", Ktema 8 (1983) 39-52.

M. FUSILLO, "Le conflit des émotions: un topos du roman grec érotique", Museum Helveticum 47 (1990) 201-221.

M. FUSILLO, "Textual patterns and narrative situations in the Greek novel", Groningen Colloquia on the novel, I (1988) 17-31.

Th. HAGG, The novel in Antiquity (Berkeley and Los Angeles, 1983).

D. KONSTAN, Sexual symmetry (Princeton, 1994).

B. P. REARDON, The form of Greek romance (Princeton, 1991).

B. P. REARDON, "Theme, structure and narrative in Chariton", YCIS 27 (1982) 1-27.

G. L. SCMELING, Chariton (New York, 1974).

S. WIERSMA, "The ancient Greek novel and its heroines: a female paradox", Mnemosyne 43 (1990) 109-123. 